\title{
Nutritional adaptations of native plants of the cerrado biome in acid soils
}

\author{
Mundayatan Haridasan*
}

Universidade de Brasília, Instituto de Ciências Biológicas, Departamento de Ecologia, CP 04457, Brasília DF 70904970, Brazil. *Corresponding author: hari@unb.br

Received: 25 August 2008; Accepted: 29 October 2008

Soils of the cerrado biome, mostly oxisols and deep sandy entisols, are acid, dystrophic and poor in available nutrients. These soils are not very different from soils that occur in the Amazon region. However, the open savanna physiognomies of cerrado with lower biomass of their different components are deficient in nutrients at the ecosystem level, unlike the Amazon forests which retain high nutrient reserves in their live biomass. Field crops are susceptible to aluminum and manganese toxicities, besides nutrient deficiencies, in cerrado soils and do not grow well in the absence of liming and fertilization. However, concepts of nutrient deficiencies and toxicities, well established for cultivated plants, should not be extended to native species in natural ecosystems, indiscriminately. Many native plants in the cerrado biome are resistant or tolerant to soil conditions deemed unfavorable for cultivated plants but their geographic distribution, frequency in native communities, growth and productivity are determined by water and nutrient availability and other edaphic conditions. Species growing on acid soils are aluminum tolerant or resistant, since their capacity to absorb essential nutrients, growth and reproduction is not affected by high aluminum levels in the soil. Many common species of the cerrado, instead of excluding aluminum, absorb and transport it to leaves and accumulate it in different tissues including leaves and seeds whereas others do not survive in the absence of exchangeable aluminum, even though no specific role of Al in plant metabolism is yet established.

Key words: aluminum toxicity, latosol, mineral nutrition, soil fertility

\begin{abstract}
Adaptações de plantas nativas do cerrado em solos ácidos: Os solos do bioma cerrado, na maioria oxisols e entisols, são ácidos e distróficos, e apresentam baixa disponibilidade de nutrientes. Estes solos não são muito diferentes dos solos da região amazônica. Entretanto, as formas abertas de vegetação do cerrado com baixa biomassa de seus diferentes componentes são deficientes em nutrientes em nível do ecossistema ao contrário das florestas amazônicas que possuem uma maior reserva de nutrientes na sua biomassa vegetal. As plantas cultivadas são susceptíveis a toxicidade de alumínio e manganês nos solos do cerrado independente da deficiência de nutrientes e não crescem bem na ausência de calagem e adubação. Entretanto, os conceitos de deficiência de nutrientes e toxicidade, bem estabelecidos na agricultura, não devem ser estendidos às plantas nativas em ecossistemas naturais, indiscriminadamente. As inúmeras espécies das plantas nativas que ocorrem no bioma são resistentes ou tolerantes às condições edáficas consideradas desfavoráveis às plantas cultivadas, mas sua distribuição, freqüência nas comunidades nativas, crescimento e produtividade são determinados pela disponibilidade de nutrientes, regime hídrico do solo e outros fatores edáficos. As espécies crescendo em solos ácidos são tolerantes ou resistentes ao alumínio por que sua capacidade de absorção de nutrientes essenciais, crescimento e reprodução não são prejudicados por altas concentrações de alumínio no solo. Muitas espécies comuns do cerrado, em vez de excluir, absorvem grandes quantidades deste elemento e transportam para folhas e acumulam em diferentes tecidos incluindo folhas e sementes e alguns não sobrevivem na ausência do alumínio trocável apesar de não ter comprovado nenhum papel deste elemento no metabolismo das plantas.
\end{abstract}

Palavras-chave: fertilidade do solo, Latossolo, nutrição mineral, toxicidade de alumínio 


\section{INTRODUCTION}

The cerrado region consists of a mosaic of vegetation physiognomies determined not only by the climate of the region, but also by soils originating from different parent materials. Many ecologists make a distinction between the cerrado domain and the cerrado biome as related to the native vegetation occurring in the Planalto region of central Brazil. Not all vegetation types which occur in the cerrado domain belong to the cerrado biome (Coutinho, 1978, 2006). Semideciduous and deciduous forests, mesophytic interfluvial forests, gallery forests and veredas are thus excluded from the cerrado biome though they are an integral part of any natural landscape in central Brazil (Ratter et al., 1977, 1978; Oliveira-Filho et al., 1989; Araújo et al., 2002; Ruggiero et al., 2002). The savanna physiognomies cerradão, cerrado sensu stricto, campo sujo and campo limpo are accepted to be part of the cerrado biome. The changes in vegetation physiognomy in the cerrado biome are associated with variations in soil depth, presence of concretions in the profile, differences in water regimes and depth of water table (Eiten, 1972; Furley and Ratter, 1988; Haridasan, 1994). Vegetation physiognomies are modified by water regimes and drainage patterns at small watershed levels where topographic features play an important role (Ruggiero et al., 2006).

An important aspect of the cerrado vegetation is not only the high biodiversity of tree species (Castro et al., 1999; Ratter et al., 2003) but also the coexistence of trees, shrubs and a herbaceous layer (Gardner, 2006). Any hectare of cerrado sensu stricto or cerradão may have up to 70 tree species, with a similar number of shrub species. The estimate of total number of woody species in the whole biome varies from 1000 to 2000 (Castro et al., 1999; Ratter et al., 2003) while the number of vascular plants is estimated to be at least 6670 (Mendonça et al., 1998). However, few species occur throughout the cerrado biome, and recognition of geographic patterns is fairly recent (Ratter et al., 2003). Ecophysiological adaptations in response to seasonal variations in precipitation and temperature regimes, besides edaphic factors, should contribute to the existence of these patterns since the cerrado biome includes disjunct areas in the Amazons besides the large core region in central plateau.

\section{NUTRIENT AVAILABILITY IN SOILS}

Soil acidity and availability of calcium and magnesium: Soils of the cerrado biome, mostly oxisols and sandy entisols, are acid, dystrophic and poor in available nutrients (Lopes and Cox, 1977; Haridasan, 1994). Alfisols with medium to high levels of $\mathrm{Ca}$ and $\mathrm{Mg}$ throughout the profile are very unusual in the cerrado physiognomies. Many researchers have suggested in the past that low fertility of the soils (Alvim and Araújo, 1952; Arens, 1958), associated with soil acidity and toxicities of aluminum (Goodland, 1971a, b) could be determinants of the vegetation physiognomies, while many still correlate the occurrence and distribution of species with availability of nutrients in the surface soil. The scope of these investigations was generally very constrained, and conclusions are of limited value for several reasons.

First of all, correlations do not establish cause and effect relationships and some of the soil properties like soil organic matter content could be reflecting feedback effects of vegetation rather than the influence of soil on vegetation. Secondly, soil fertility or the availability of nutrients is not the only factor, or the primary factor, determining productivity and distribution of species. Other edaphic factors like effective soil depth, presence of concretions and other barriers to root growth and soil water regimes may well play primary roles in the distribution of species and vegetation physiognomies, even within small watersheds. Third, the nutrient availability in the soil under present conditions does not represent past conditions during soil development and vegetation establishment, and was not responsible for the buildup of large biomass in some ecosystems, like tropical rainforests. The focus of the following discussion is on the adaptations of native species in acid soils, which are mostly dystrophic and well-drained. It is argued that the vegetation form of cerrado sensu stricto developed under conditions of poor nutrient availability in the past during soil development and vegetation establishment.

The most important aspect in this regard is that there are large areas of mesotrophic or even eutrophic soils with considerably higher levels of $\mathrm{Ca}$ and $\mathrm{Mg}$ occurring within the cerrado domain. Interestingly, the semideciduous and deciduous forests vegetations which 
these soils support are excluded from the concept of cerrado biome by Coutinho (1978, 2006). It is not necessary that soils be mesotrophic or eutrophic for the forest vegetation to be semideciduous or deciduous. The definition of eutrophic soils in the Brazilian system of soil classification is that the base saturation of soils be higher than $50 \%$. On the other hand, in Australian system of soil classification mesotrophic soils are defined as soils with a base status between 5 and $15 \mathrm{cmol}_{\mathrm{c}} \mathrm{kg}^{-1}$ clay and eutrophic soils as those with a base status above 15 $\mathrm{cmol}_{\mathrm{c}} \mathrm{kg}^{-1}$ clay (Isbell, 2002). Normally exchangeable Ca levels above $2 \mathrm{cmol}_{\mathrm{c}} \mathrm{kg}^{-1}$ are enough for the vegetation to be semideciduous or deciduous on well drained soils (Ratter et al., 1977, 1978; Ruggiero et al., 2002, 2006). The floristic composition of the deciduous forests is very different from that of the cerrado formations (Souza et al., 2007). Differences in calcium availability in well drained soils imply in changes in floristic composition even in cerradão, a forest formation considered to be part of the cerrado biome (Araújo and Haridasan, 1988).

The soil $\mathrm{pH}$ of cerrado sensu stricto and associated open physiognomies is always acid (median $=5$ in soilwater suspension, Lopes and Cox, 1977). Soil pH influences the availability and deficiency of nutrients at one extreme, and toxicity at the other extreme, independent of their total concentrations in the soil mineral matrix. For example, aluminum, manganese and iron toxicities occur at low soil $\mathrm{pH}$. Aluminum is toxic to many crop plants when $\mathrm{pH}$ drops below 5 when $\mathrm{Al}^{3+}$ and $(\mathrm{AlOH})^{2+}$ come into solution. Mn toxicity occurs at $\mathrm{pH}$ lower than 5.6, whereas Fe toxicity occurs only at $\mathrm{pH}$ below 4 due to its oxidized form.

Major plant nutrients, N, P, K, Ca, Mg and S, are all deficient in deep oxisols and sandy entisols of the cerrado region for different reasons. In most cases, the lack of nutrients is attributed to low nutrient status of parent materials and intense losses with deep weathering. This is the case with $\mathrm{Ca}$ and $\mathrm{Mg}$ in soils derived from quartzites and sandstones and other acid rocks. Though common primary minerals, such as feldspars, are rich in $\mathrm{K}$, cerrado soils have low quantities of $\mathrm{K}$ because of intense leaching during soil development. Soils which develop in the tropics under well-drained conditions, like latosols (oxisols), do not usually accumulate large quantities of organic matter because of intense decomposition processes, and do not have high organic matter concentrations in the surface layers. Since $\mathrm{C} / \mathrm{N}$ ratios are fairly stable, total and available $\mathrm{N}$ are related to the total organic carbon content and therefore also low in the cerrado soils. Soil available P is also very low, except in case of soils derived from basalt or mafic parent materials (Rezende et al., 2005).

The nutrient poor cerrado soils today are not very different from the soils that occur in the Amazon region which support more luxuriant vegetations with much higher live biomass (Table 1). Further, there is little floristic similarity between native plant communities of the open formations of the cerrado and the Amazon forests. The essential difference between these two biomes refers to the higher nutrient stock, especially of $\mathrm{Ca}$ and $\mathrm{Mg}$ in the live biomass in the Amazon forests (Haridasan, 2000, 2001; Lilienfein et al., 2001). This may be a consequence of past availability of these nutrients during the establishment of the natural vegetation. On other hand, the absence of high biomass in the open forms of cerrado vegetation leads us to the conclusion that nutrients were the main limiting factor for vegetation formation during the past where other edaphic factors were generally favorable for tree growth. The availability of nutrients and acidity of soils in the two biomes today are comparable, and there is no correlation between general soil fertility status and live biomass of native communities. Many Amazon species would grow well in the cerrado region if nutrients are supplied through fertilization. Thus there is no reason to argue that acid soils are detrimental to the growth of native plant species, except when nutrients are limiting. The only logical argument is that cerrado species can thrive under low fertility conditions.

The role of Ca in forest productivity is yet to be best understood though it is well accepted that Ca exerts a significant control on both structure and function of forest ecosystems (McLaughlin and Wimmer, 1999). Even in tropical forests, where the amount of Ca stored in the wood biomass is very high, it could be a limiting factor for root growth (Cuevas and Medina, 1986). Several field and pot culture studies have shown that cerrado species respond to addition of lime by taking up $\mathrm{Ca}$ and $\mathrm{Mg}$ (Villela and Haridasan, 1994; Silva, 2001).

Nitrogen and phosphorus: Nitrogen and phosphorus are the other two nutrients which have received major attention of researchers dealing with natural ecosystems 
Table 1. Soil properties of two typical Latosol (Oxisol) profiles associated with natural vegetations of a cerrado sensu stricto in central Brazil and a terra firme forest in the Amazon in northern Brazil (RadamBrasil, 1976a, b).

\begin{tabular}{|c|c|c|c|c|c|c|c|c|c|}
\hline \multirow[t]{3}{*}{ Horizon } & \multirow{2}{*}{$\begin{array}{l}\text { pH in } \\
\text { water }\end{array}$} & \multirow{2}{*}{$\begin{array}{c}\mathrm{pH} \text { in } \\
\mathrm{KCl}\end{array}$} & \multirow{2}{*}{$\begin{array}{l}\text { Organic } \\
\text { carbon }\end{array}$} & \multirow[t]{2}{*}{$\mathrm{N}$} & \multirow[t]{2}{*}{$\mathrm{P}$} & \multicolumn{4}{|c|}{ Exchangeable cations } \\
\hline & & & & & & $\mathrm{Ca}$ & $\mathrm{Mg}$ & $\mathrm{K}$ & Al \\
\hline & & & $\%$ & $\%$ & $\mathrm{mg} \mathrm{kg}^{-1}$ & \multicolumn{4}{|c|}{$\mathrm{Cmol}(+) \mathrm{kg}^{-1}$ soil- } \\
\hline \multicolumn{10}{|c|}{ Cerrado sensu stricto (State of Mato Grosso $15^{\circ} 25^{\prime} \mathrm{S} ; 5^{\circ} 12^{\prime} \mathrm{W}$ ) } \\
\hline \multicolumn{10}{|c|}{ Profile 19. Latossolo Vermelho Amarelo (Acrorthox), p. 230, Vol. 10, Folha SA21 Santarém. } \\
\hline$A_{1}$ & 5.0 & 4.2 & 0.8 & 0.06 & $<0.1$ & 0.22 & 0.09 & 0.06 & 0.30 \\
\hline$A_{3}$ & 5.0 & 4.2 & 0.5 & 0.05 & $<0.1$ & 0.28 & 0.06 & 0.02 & 0.30 \\
\hline $\mathrm{B}_{1}$ & 5.0 & 4.3 & 0.4 & 0.04 & $<0.1$ & 0.24 & 0.10 & 0.03 & 0.20 \\
\hline$B_{2}$ & 5.2 & 4.3 & 0.2 & 0.03 & $<0.1$ & 0.18 & 0.11 & 0.05 & 0.30 \\
\hline \multicolumn{10}{|c|}{ Amazon forest (State of Pará - $1^{\circ} 13^{\prime} \mathrm{S} ; 5^{\circ} 56^{\prime} \mathrm{W}$ ) } \\
\hline \multicolumn{10}{|c|}{ Profile 129. Latossolo Amarelo (Haplorthox), p. 390, Vol. 25, Folha SD20 Goiás. } \\
\hline $\mathrm{A}_{1}$ & 4.5 & 4.0 & 1.65 & 0.24 & $<0.1$ & 0.29 & 0.12 & 0.10 & 3.15 \\
\hline $\mathrm{A}_{3}$ & 4.8 & 4.2 & 1.51 & 0.15 & $<0.1$ & 0.23 & 0.06 & 0.04 & 1.97 \\
\hline $\mathrm{B}_{1}$ & 5.2 & 4.8 & 0.62 & 0.09 & $<0.1$ & 0.21 & 0.03 & 0.03 & 1.18 \\
\hline $\mathrm{B}_{2}$ & 5.4 & 5.1 & 0.55 & 0.06 & $<0.1$ & 0.20 & 0.03 & 0.03 & 0.98 \\
\hline
\end{tabular}

(Lathwell and Grove,1986; Davidson and Howarth, 2007; Elser et al., 2007). Phosphorus is a limiting factor for most agricultural crops and the organic fraction of $\mathrm{P}$ is considered to be an important source of plant available $\mathrm{P}$ in native soils (Chapuis-Lardy et al., 2001). Nitrogen is reported to be limiting in tropical savannas (Bustamante et al., 2006). However, as Lathwell and Grove (1986) pointed out, there is virtually no direct evidence that native terrestrial ecosystems are nutrient limited and it is extremely difficult to demonstrate nutrient limitations without disrupting native ecosystems. The concept of deficiency in natural ecosystems is often an extension of the results of agronomic experiments in which crop plants respond positively to addition of nutrients in terms of uptake of nutrients and production of biomass. Vitousek (1984) was one of the earliest to suggest that P but not N commonly limited production of tropical rain forests. Recently, Neri (2007) showed the importance of total P levels in soil, rather than available $\mathrm{P}$, as a factor controlling cerradão-cerrado sensu stricto physiognomies in Paraopeba, Minas Gerais.

Though several authors have tried to analyze N/P correlations in leaf concentrations in natural communities, what is evident so far is that there are large interspecific variations in native communities (Townsend et al., 2007) and either $\mathrm{N}$ or $\mathrm{P}$ is supplied, Liebig's law of the minimum comes into play (Davidson and Howarth, 2007) besides individual responses of different species. There is no satisfactory theoretical explanation as yet for the stochiometric relationship observed between $\mathrm{N}$ and $\mathrm{P}$ across several species. Aerts and Chapin (2000) suggested that $\mathrm{N} / \mathrm{P}$ ratios above 16 indicate $\mathrm{P}$ deficiencies and ratios below 14 indicate $\mathrm{N}$ deficiencies. In native plant communities of cerrado, foliar nutrient concentrations as well as nutrient ratios vary widely even among woody species over small areas on homogenous soils (Haridasan, 2005; Araújo and Haridasan, 2007). While some species show N/P ratios indicative of $\mathrm{P}$ deficiency others show ratios indicative of $\mathrm{N}$ deficiency. Fertilizer response studies involving native species are too few yet for any general conclusions but preliminary results indicate that cerrado species respond to both $\mathrm{N}$ and P (Kozovits et al., 2007; Bucci et al., 2006).

\section{MINERAL NUTRITION OF NATIVE PLANTS}

With extremely successful agricultural research, there is a vast amount of information available on the nutritional requirements of agricultural crops as well as forest species such as eucalyptus and pines in the literature. New varieties which tolerate acid soil conditions and respond better to fertilizers have led to increased production all over the world. Optimizing costs of production is a high priority in agricultural research. However insights into the functioning of natural ecosystems are rather limited. This is particularly true of ecosystems such as cerrado whose primary characteristic 
is a high biodiversity of the native plant communities trees, shrubs, herbs and grasses - on nutrient poor acid soils. Although we have the technology to cultivate high yielding crop plants in these soils with the application of lime, fertilizers and irrigation, we know very little about different aspects of mineral nutrition, water use and photosynthetic efficiencies of several hundred species of native plants which exist on nutrient poor soils.

Discussions on nutrient deficiencies in the cerrado biome before the 1980's were generally focused on poor nutrient availability and acid conditions of soils without due emphasis on the adaptations of native species which enable them to survive under these conditions and provide necessary resilience to an extremely diverse mosaic of plant physiognomies in the region (Goodland, 1971a, b; Goodland and Pollard, 1973; Lopes and Cox, 1977). This seemed to be natural at a time when there were few investigations of native plants, except by plant taxonomists, and an agronomic approach was adopted by researchers who looked into soil fertility, trying to associate plant physiognomies and species distribution with soil fertility (Alvim and Araújo, 1952; Arens, 1958). The roles of recycling of essential macronutrients in natural ecosystems and adaptations to water and nutrient stress have only been investigated during the last couple of decades in an attempt to understand the functioning of these ecosystems (Haridasan, 2001; Franco, 2002, 2005; Prado et al., 2004; Narodoto et al., 2006).

In spite of the increasing interest in protecting natural ecosystems and conserving biodiversity, very little research is being reported on different aspects of mineral nutrition of native plants of the cerrado biome. Isolated studies of litter decomposition and effects of fire at community levels, and adaptations and responses of individual species to additions of nutrients are more common. There are inherent difficulties in characterizing the nutritional status of natural plant communities such as cerrado with high biodiversity of different functional groups such as trees, shrubs and herbs. In comparing communities on different soils, the presence of species which occur only on certain soils or plant communities confounds environmental effects with interspecific variations. Further not all species occurring in a native community have the same importance in the ecosystem function because of their relative frequency and dominance.

Leaf analysis of native plants of cerrado communities shows that nutrient concentrations are generally low in the physiognomies characteristic of the cerrado biome (Haridasan, 1987, 1992, 2005; Lilienfein et al., 2001). Gallery forests and semideciduous forests which occur in the cerrado domain generally have higher nutrient concentrations (Nogueira and Haridasan, 1997; Haridasan and Araújo, 2005). The nutrient requirements of the herbaceous layer, which is an essential component of the savanna vegetation is extremely low assuring high resilience to the cerrado ecosystem after disturbances like fire (Batmanian and Haridasan, 1985; Villela and Haridasan, 1994). It has been shown that many native woody species respond positively to higher availability of nutrients through fertilization (Moraes, 1994; Silva 2001; Coradin et al., 2002). The ground layer vegetation which consists mainly of grasses responds to fertilization, absorbing more nutrients and producing higher biomass (Villela and Haridasan, 1994). The response of community as a whole to higher fertility would involve changes in tree-grass equilibrium since higher biomass accumulation by trees would increase shading affecting adversely the shrub and herbaceous layer. Higher litter production by the tree community would be another consequence (Silva, 2001).

Several adaptive mechanisms such as root dimorphism (Sternberg et al., 2005) nocturnal transpiration (Bucci et al., 2004), resorption of nutrients before senescence of leaves (Nardoto et al., 2006), recycling of nutrients from litter (Silva, 2001) and mycorrhyzal associations (Reis, 1999) could be involved in making native plant communities more efficient than cultivated plants in poor soils and sustaining the ecosystem functions.

In spite of the high biodiversity of tree species in native communities, a few species constitute major part of the standing biomass and its nutrient reserve on dystrophic soils. The nutrient concentrations in leaves vary widely but the more abundant species seem to be less exigent with lower foliar concentrations and there is no evidence of interspecific competition for nutrients (Haridasan, 2005). However, the geographic distribution of species varies very widely over the whole biome (Ratter et al., 2003) and the more abundant species in any given community varies. An extreme case is the cerrado of Roraima in the Amazon region where three woody species (Curatella americana L. (Dilleniaceae), Byrsonima 
crassifolia (L.) Kunth. (Malpighiaceae) and B. coccolobifolia Kunth. (Malpighiaceae) constitute more than $80 \%$ of the biomass of the tree biomass (Barbosa e Fearnside, 2004).

\section{ADAPTATIONS TO HIGH ALUMINUM LEVELS IN SOILS}

Aluminum toxicity is an important research topic since many cultivated plants are susceptible in acid soils and their growth and yield are adversely affected by high levels of available Al in the soil (Mariano et al., 2005; Silva et al., 2002; Vitorello et al., 2005). However, very little attention has been paid to native plant communities which tolerate acid soil conditions over large areas in different biomes. Aluminum-tolerating species include $\mathrm{Al}$ excluders which have a wide range of mechanisms to avoid aluminum uptake and $\mathrm{Al}$ accumulators defined as plants with foliar Al concentrations above $1000 \mathrm{mg} \mathrm{kg}^{-1}$.

The question of Al toxicity in cerrado ecosystems was first raised by Goodland (1971b) who suggested that scleromorphism exhibited by many of the cerrado species could be associated with aluminum toxicity in the acid soils. Based on the reports of Hutchinson (1943), Chenery (1948 a, b) and Webb (1954), who identified plant species which accumulate $\mathrm{Al}$ from Australia and other parts of the world, he formulated the hypothesis that plants belonging to families such as Vochysiaceae and Melastomataceae could be aluminum accumulators. This has proven to be the case in recent studies (Haridasan, 1982, 1987). However, it has been shown that these species do not show lower concentrations of other essential nutrients as compared to nonaccumulators, and Al does not inhibit their growth.

Often, in native cerrado physiognomies a few accumulator species constitute a large percentage of individuals belonging to the tree community, probably due to some competitive advantage under acid soil conditions. For example, only 5 of the 38 tree species in a cerrado sensu stricto at the Fazenda Água Limpa in the Federal District were aluminum accumulators, but they accounted for $30 \%$ of the total importance value in the community (Haridasan, 1987). Some of these are among the most widespread species of the cerrado region (Ratter et al., 2003). However, aluminum accumulators are not restricted to dystrophic acid soils. Callisthene fasciculata Mart. (Vochysiaceae), an aluminum accumulator occurs only on mesotrophic soils (Haridasan and Araújo, 1988). Another accumulating species, Qualea grandiflora Mart. (Vochysiaceae) occurs both in dystrophic and mesotrophic soils, but interestingly takes up more $\mathrm{Al}$ and $\mathrm{Ca}$ from mesotrophic soils (Haridasan, 1987). Some species such as Miconia albicans (Sw.) Triana (Melastomataceae) and Vochysia thyrsoidea Mart. (Vochysiaceae) (Figure 1) do not grow in the absence of $\mathrm{Al}$ in nutrient solutions (Machado, 1985; Haridasan, 1988). The seedlings of these species fail to grow on calcareous soils showing yellowing and necrosis of new leaves (Figures 2 and 3) but when transplanted to acid soils recover their vigor and continue normal growth (Figure 4). New leaves which appear after transplanting to acid soils (Figure 5) have high concentrations of aluminum common in accumulator species (4000-1000 mg kg${ }^{-1}$ ) whereas necrotic leaves present very low concentrations of Al. The presence of Al in large concentrations in roots and different tissues of leaves has been demonstrated by staining (Figure 6) and electron microprobe analysis (Haridasan et al., 1987). Aluminum is transported via phloem in these species and concentrations of $\mathrm{Al}$ in the seeds are also very high (Table 2).

It has not been possible to manipulate the absorption of $\mathrm{Al}$ in aluminum accumulating species as a function of its concentration in the growth media or to demonstrate that $\mathrm{Al}$ concentration increases with its availability in soil (Machado, 1985). When lime was added to the soil around the adult plants of Vochysia thyrsoidea Pohl on an acid latosol, in spite of the increase in soil $\mathrm{pH}$ the foliar concentration of $\mathrm{Al}$ went up as did the concentration of $\mathrm{Ca}$, raising the possibility that calcium channels were probably involved in aluminum transport also. The only known case of a plant which performs well in the presence as well as the absence of aluminum is that of the hemiparasite, Phthirusa ovata, which accumulates aluminum only when it grows on an accumulating host plant (Lüttge et al., 1998). It has been shown that the mistletoe receives much more $\mathrm{Al}$ from accumulating than non-accumulating hosts and that their photosynthetic apparatus and stomatal regulation were well adapted to increased Al-levels as there was no increased photoinhibition or reduced transpirational cooling in the presence of $\mathrm{Al}$. This is evidence that $\mathrm{Al}$ is not playing any 


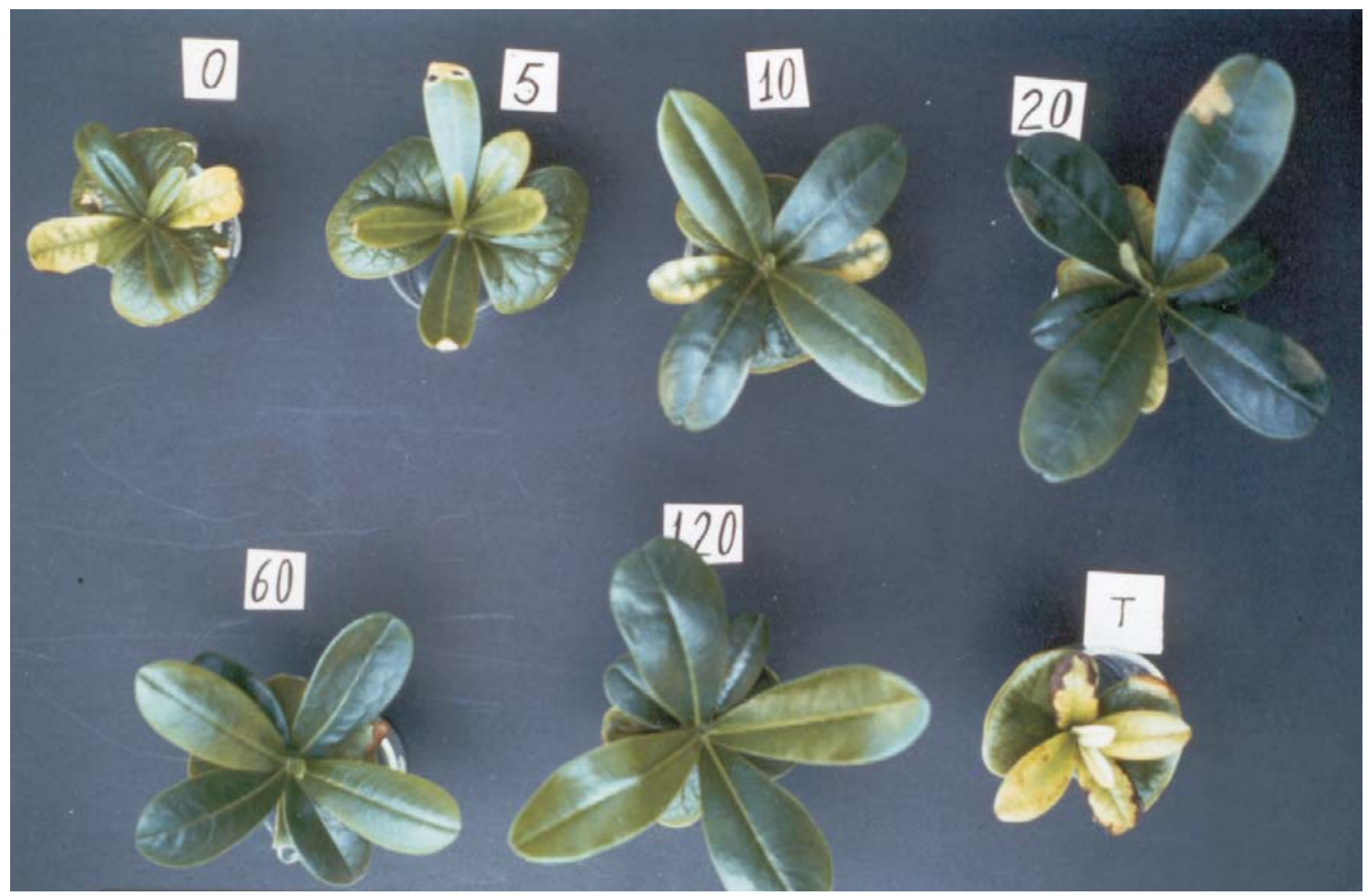

Figure 1. Chlorosis of leaves of Vochysia thyrsoidea Pohl in the absence of aluminum in the growth medium (top left, 0 $\mathrm{mg} \mathrm{L}^{-1}$, and bottom right, tap water) in contrast with healthy leaves in the presence of 5 to $120 \mathrm{mg} \mathrm{L}^{-1}$.

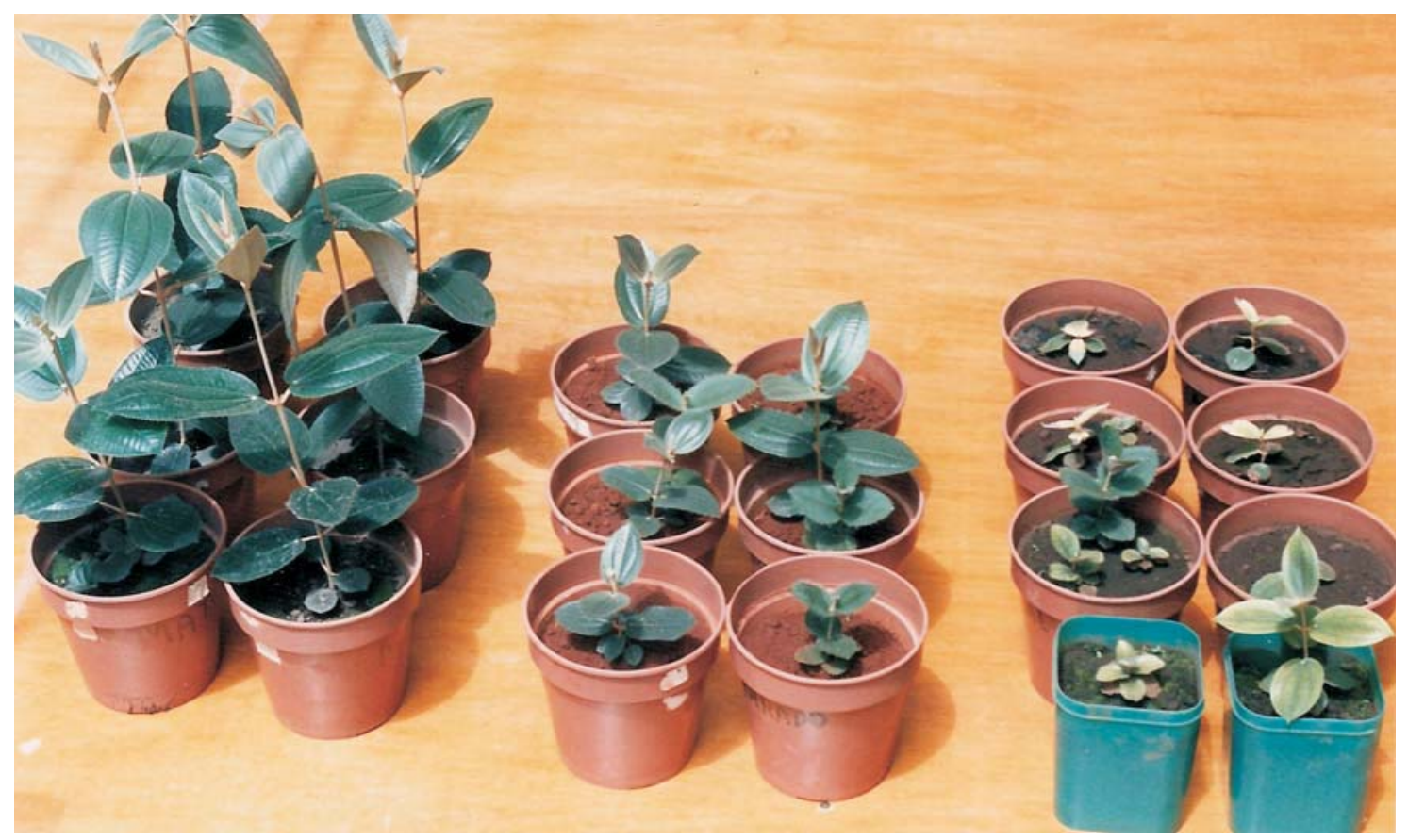

Figure 2. Seedlings of Miconia albicans (Sw.) Triana, an aluminum accumulator, growing in a fertile acid gallery forest (to the left), poor acid cerrado (center) and alkaline calcareous (right) soils. Note chlorotic leaves and stunted growth in calcareous soils. 

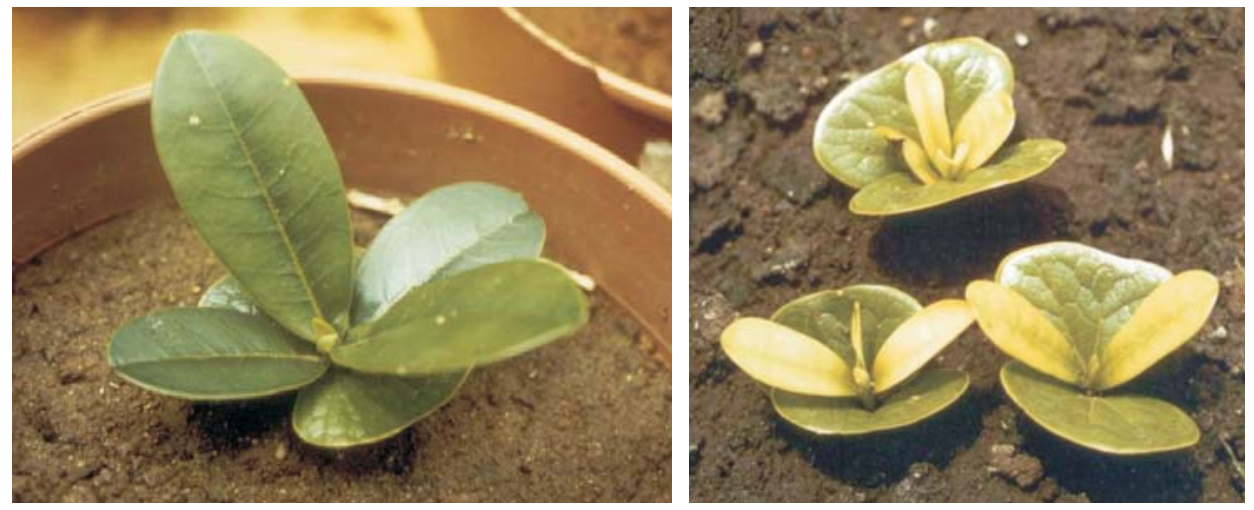

Figure 3. Seedlings of Vochysia thyrsoidea Pohl growing in an acid soil with healthy green leaves (left) and in a calcareous soil with chlorotic leaves (right).

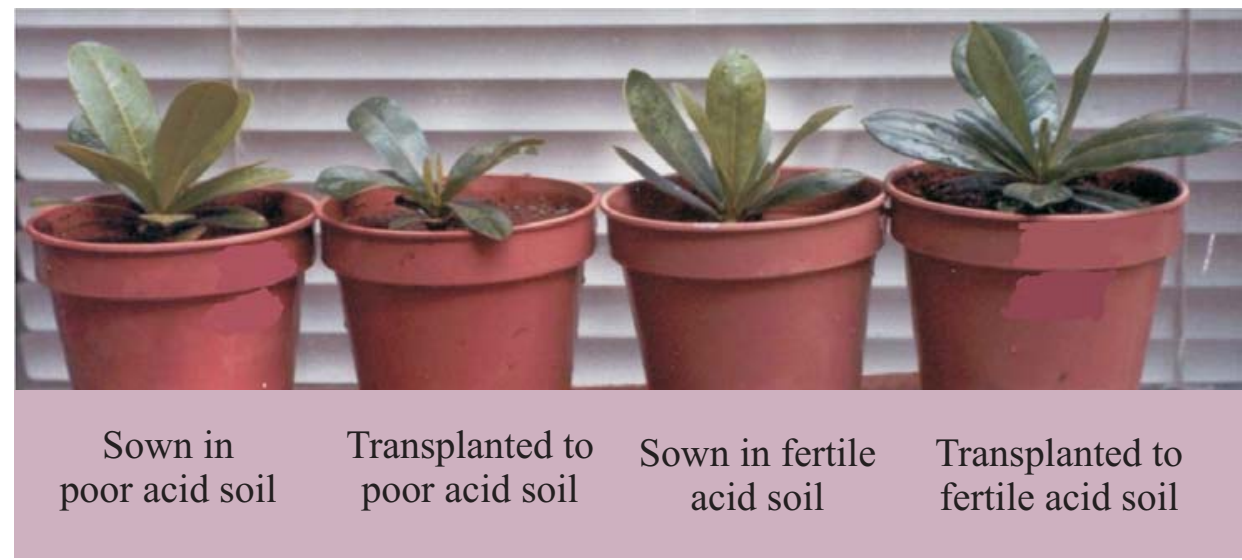

Figure 4. Vochysia thyrsoidea seedlings sown in acid soils and recovery after transplanting from a calcareous to an acid soil.

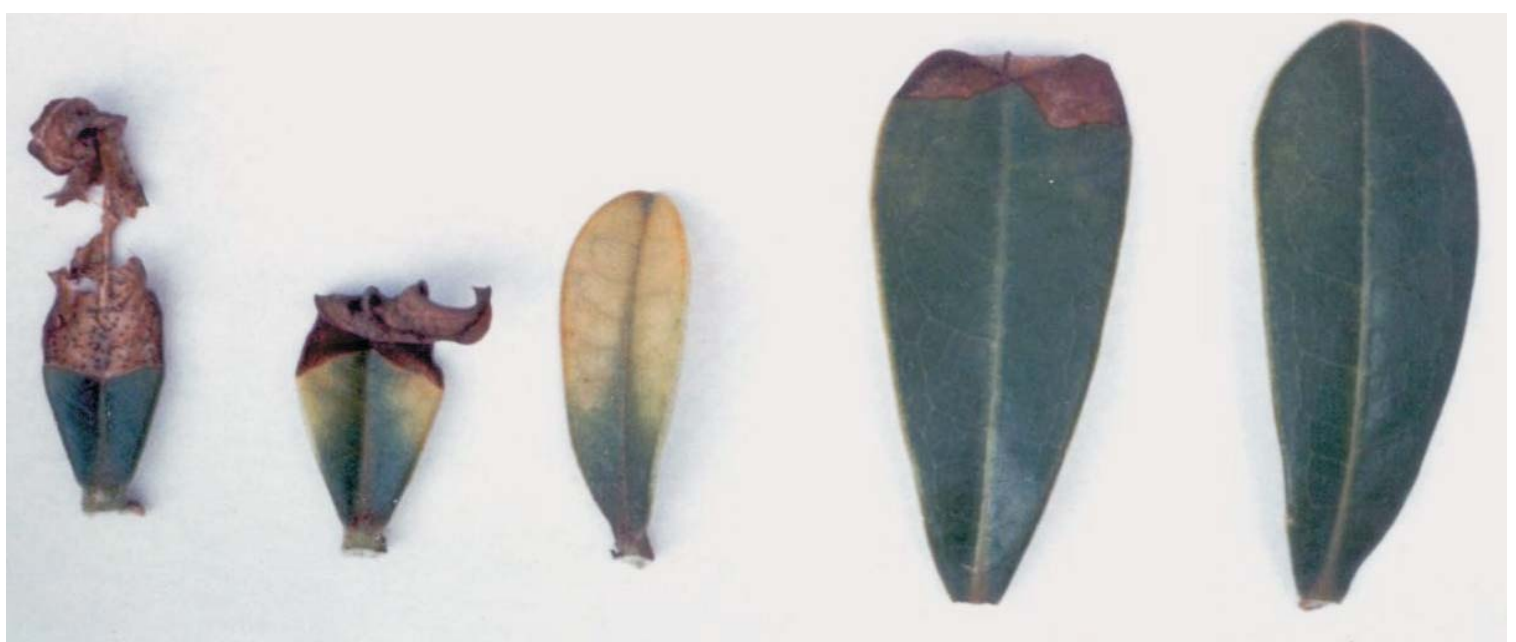

Figure 5. Recovery of the leaves of Vochysia thyrsoidea Pohl seedlings transplanted from a calcareous soil to an acid soil.

Braz. J. Plant Physiol., 20(3):183-195, 2008 


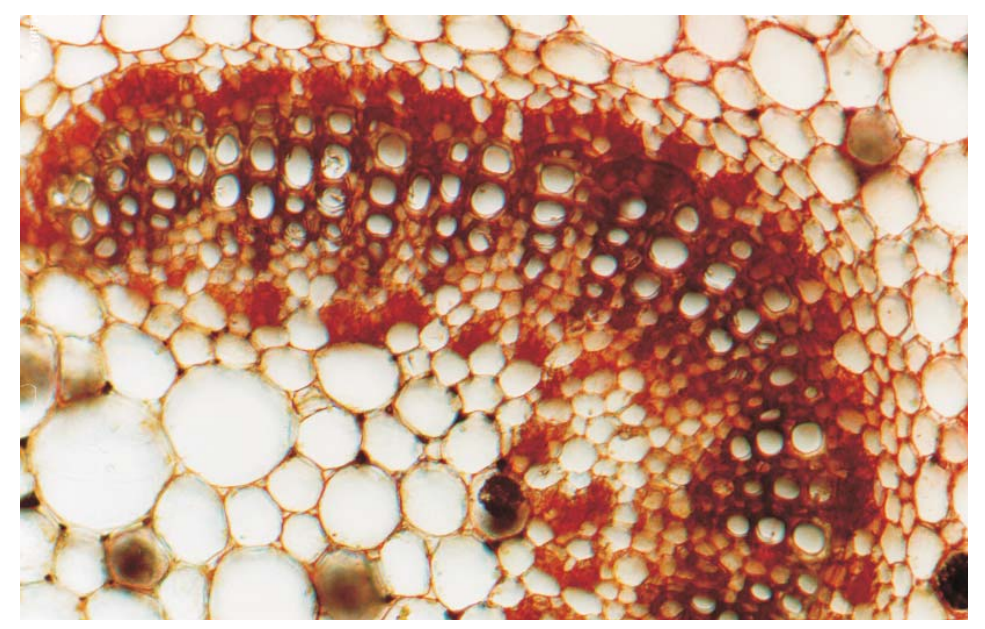

Figure 6. Localization of aluminum in the leaf tissues of Vochysia thyrsoidea Pohl using aluminon.

Table 2. Concentration of aluminum $(n=3)$ in the seeds of some Al-accumulating species of the cerrado vegetation (Haridasan, 1987).

\begin{tabular}{|c|c|c|}
\hline Family & Species & Concentration of $\mathrm{Al}\left(\mathrm{g} \mathrm{kg}^{-1}\right)$ \\
\hline \multirow[t]{2}{*}{ Melastomataceae } & Miconia albicans (Sw.) Triana & 6.9 \\
\hline & Miconia pohliana Cogn. & 5.3 \\
\hline Rubiaceae & Palicourea rígida H.B.K. & 6.0 \\
\hline \multirow[t]{6}{*}{ Vochysiaceae } & Qualea parviflora Mart. & 4.8 \\
\hline & Qualea multiflora Mart. & 20.2 \\
\hline & Salvertia convallariodora St. Hil. & 28.4 \\
\hline & Vochysia rufa (Spr.) Mart. & 28.4 \\
\hline & Vochysia thyrsoidea Pohl & 36.5 \\
\hline & Vochysia tucanorum Mart. & 40.5 \\
\hline
\end{tabular}

essential role in the metabolism of the hemiparasite, on the one hand, and that it does not, on the other, interfere in the form it is absorbed from the host plant or is transported within the hemiparasite.

Recent phylogenetic evidence shows that aluminum accumulation has evolved independently in several plant groups that are not closely related (Jansen et al., 2003). Ninety-three percent of all accumulators belong to higher angiosperm groups of asterids and rosids. Within these groups, aluminum accumulation is largely restricted to two orders, Myrtales and Gentianales, which consist of several closely related families. In general, aluminum accumulation is a common feature of large taxonomic groups, such as plant families or orders, occurring over very large geographic areas with high biodiversity as in tropical rainforests and savannas. There is usually no variation in the presence or absence of the feature between different plants of the same species. Thus there is no reason to argue that accumulation of $\mathrm{Al}$ is of detrimental nature in native ecosystems, though there are many species, mainly cultivated plants, which are susceptible to Al toxicity in acid soils.

\section{CONCLUSIONS}

It is evident from available information in published research that cerrado is deficient in nutrient reserves at the ecosystem level, taking into account the nutrient stock in plant biomass and soil. This is a more meaningful way to compare cerrado with other natural ecosystems like Amazon forests, for example, which has a much higher plant biomass but not necessarily more fertile soils at present. It is often argued that high acidity associated with aluminum toxicity and low fertility are limiting factors in 
this ecosystem resulting in the characteristic open savanna physiognomies. This is true in the case of cultivated field crops which respond to liming and fertilizer applications and whose growth is affected by toxicity in acid soils and whose yields are very low in the absence of liming and fertilization. However, concepts of nutrient deficiencies and toxicities, well established for cultivated plants, should not be extended to native species in natural ecosystems indiscriminately. Several adaptive mechanisms such as root dimorphism, nocturnal transpiration, resorption of nutrients before senescence of leaves, recycling of nutrients from litter and mycorrhyzal associations could be involved in making native plant communities more efficient than cultivated plants in poor soils. This does not mean that such species would not respond positively to better availability of nutrients, water or other resources like light, or in the absence of competition which restricts growth and productivity in natural communities. The growth and reproduction of most species growing on acid soils are not affected by aluminum toxicity. Many common species of the cerrado, instead of excluding aluminum, absorb and accumulate it in large quantities in their tissues including leaves and seeds. This seems to be a successful strategy among several native species in the highly acid soils since few accumulating species account for a large number of individuals in native plant communities.

\section{FUTURE RESEARCH}

Our present knowledge of plant ecophysiology is mainly based on research on cultivated plants, especially under restricted conditions, either in greenhouses or in fields under conditions of adequate fertilization and irrigation. Models of response to fertilizers and irrigation, on the one hand, and to amelioration of adverse conditions such as soil acidity, deficiencies of nutrients, toxicities and salinity are extrapolated to field conditions often far beyond the experimental set up without sufficient care.

The biodiversity of natural tropical ecosystems surpasses our imagination. It is not only the number of species of higher plants or life forms that matters. Many plant species are distributed over large geographical areas with combinations of extremely adverse conditions such as drought or water logging, high to freezing temperatures, dystrophic to eutrophic and saline soils and seasonal variations in day length and rainfall. Very little information is available on these plants in natural plant communities. Generalizations are therefore made based on information available from research on cultivated plants or a few native species. This is inadequate especially in a scenario where genetic engineering could take advantage of successful traits of native plants to improve the performance of economically useful plants. An example of this is the capacity of cerrado plants to survive in acid soils with low nutrient availability without succumbing to aluminum toxicity. Another aspect is the capacity of native plants to survive under drought conditions of low water and nutrient availability in the surface soil for up to five months. It is believed that many native species can make use of fractions of phosphorus in the soil considered to be unavailable to crop plants. Also environmental concerns make it imperative that we use native species in the recovery of degraded lands and agroforestry systems, reducing to a minimum the use of fertilizers and irrigation, not only to protect soil but also to increase carbon sequestration. A better understanding of native species is also essential for the nondestructive economic exploration of tropical forests and other ecosystems.

Acknowledgements: The author wishes to thank Dr. José Wagner Borges Machado for providing the photos in Figures 1 and 3 to 5, and Dr. Guillermo Goldstein, Dr. Carlos Ernesto Gonçalves Reynaud Schaefer and Dr. Augusto Cesar Franco for their helpful comments on the manuscript.

\section{REFERENCES}

Aerts R, Chapin FS (2000) The mineral nutrition of wild plants revisited: a re-evaluation of processes and patterns. Advances in Ecological Research 30:1-67.

Alvim PT, Araújo WA (1952) El suelo como factor ecológoco en el desarrolo de la vegetación en el centro oeste del Brasil. Turrialba 2:153-160.

Araújo GM, Barbosa AAA, Arantes AA, Amaral AF (2002) Composição florística de veredas no município de Uberlândia, MG. Rev. Bras. Bot. 25:475-493.

Araújo GM, Haridasan M (1988) A comparison of the nutritional status of two forest communities on mesotrophic and dystrophic soils in central Brazil. Commun. Soil Sci. Plant Anal 19:1075-1089.

Araújo JF, Haridasan M (2007) Relação entre deciduidade e concentrações foliares de nutrientes nas espécies 
lenhosas do cerrado. Revista Brasileira de Botânica 30:533-542.

Arens K (1958) O cerrado como vegetação oligotrófico Boletim da Faculdade de Filosofia, Ciências e Letras, Universidade de São Paulo, 224. Bot. 15:59-77.

Barbosa RI, Fearnside, PM (2004) Wood density of trees in open savannas of the Brazilian Amazon, Forest Ecol. Manage 199:115-123.

Batmanian GJ, Haridasan M (1985) Primary production and accumulation of nutrients by the ground layer community of cerrado vegetation of central Brazil. Plant and Soil 88:437-440.

Bucci SJ, Scholz FG, Goldstein G, Meinzer FC, Hinojosa JA, Hoffmann WA, Franco AC (2004) Processes preventing nocturnal equilibration between leaf and soil water potential in tropical savanna woody species. Tree Physiol. 24:1119-1127.

Bucci SJ, Scholz FG, Goldstein G, Meinzer FC, Franco AC, Campanello PI, Villalobos-Vega R, Bustamante M, Miralles-Wilhelm F (2006) Nutrient availability constrains the hydraulic architecture and water relations of savannah trees. Plant Cell and Environment 29:2153-2167.

Bustamante MMC, Medina E, Asner GP, Nardoto GB, Garcia-Montiel DC (2006) Nitrogen cycling in tropical and temperate savannas. Biogeochemistry 79:209-237.

Castro AAJF, Martins FR, Tamashiro JY, Shepherd GJ (1999) How rich is the flora of the Brazilian cerrados? Annals of the Missouri Botanical Garden 86:192-224.

Chapuis-Lardy L, Brossard M, Quiquarnpoix H (2001) Assessing organic phosphorus status of Cerrado oxisols (Brazil) using 31P-NMR spectroscopy and phosphomonoesterase activity measurement. Can. J. Soil Sci. 81:591-601.

Chenery EM (1948b) Aluminium in plants and its relation to plant pigments. Ann. Bot. 12:121-136.

Chenery EM (1948a) Aluminium in the plant world. Part I. General survey in the dicotyledons. Kew Bull 3:173-183.

Coradin VTR, Haridasan M, Souza MR, Silva MEF (2002) Influência da calagem e da adubação no crescimento de duas espécies lenhosas do cerrado. Brasil Florestal 74:53-60.

Coutinho LM (1978) O conceito de cerrado. Rev. bras. Bot. 1:17-23.

Coutinho LM (2006) O conceito de bioma. Acta Bot. Bras. 20:13-23.

Cuevas E, Medina E (1986) Nutrient dynamics within the
Amazonian forest ecosystems. I, Nutrient flux in fine litter fall and efficiency of nutrient utilization. Oecologia 62:466-472.

Davidson EA, Howarth RW (2007) Nutrients in synergy. Nature 449:1000-1001.

Eiten G (1972) The cerrado vegetation of central Brazil. Botanical Review 38:201-341.

Elser JJ, Bracken MES, Cleland EE, Gruner DS, Harpole WS, Helmut Ngai HJT, Seabloom EW, Shurin JB, Smith JE (2007) Global analysis of nitrogen and phosphorus limitation of primary producers in freshwater, marine and terrestrial ecosystems. Ecology Letters 10:1135-1142.

Franco AC (2002) Ecophysiology of woody plants. In: Oliveira PS, Marquis RJ (eds), The cerrados of Brazil: ecology and natural history of a neotropical savanna. pp.178-197. Columbia University Press, New York.

Franco AC (2005) Biodiversidade de forma e função: implicações ecofisiológicas das estratégias de utilização de água e luz em plantas lenhosas do cerrado. In: Scariot A, Felfili JM, Sousa-Silva JC (eds), Cerrado: Ecologia, Biodiversidade e Conservação. pp. 179-196. Ministério de Meio Ambiente, Brasília.

Furley PA, Ratter JA (1988) Soil resources and plant communities of the central Brazilian cerrado and their development. J. Biogeogr. 15:97-108.

Gardner T (2006) Tree-grass coexistence in the Brazilian cerrado: demographic consequences of environmental instability. J. Biogeogr. 33:448-463.

Goodland R, Pollard R (1973) The Brazilian cerrado vegetation, a fertility gradient. J. Ecol. 61:219-224.

Goodland R (1971a) A physiognomic analysis of the cerrado vegetation of central Brazil. J. Ecol. 59:411-419.

Goodland R (1971b) Oligotrófismo e alumínio no cerrado. In: Ferri, M.G (ed), III Simpósio sobre o cerrado. pp. 4460. EDUSP, São Paulo.

Haridasan M (1982) Aluminium accumulation by some cerrado native species of central Brazil. Plant Soil 65:265-273.

Haridasan M (1987) Distribution and mineral nutrition of aluminium-accumulating species in different plant communities of the cerrado region of Central Brazil. In: San José JJ, Montes R (eds), La capacidad bioproductiva de sabanas. pp.309-348. Instituto Venezolano de Investigaciones Cientificas, Caracas.

Haridasan M (1988) Performance of Miconia albicans (Sw.) Triana, an aluminium accumulating species in 
acidic and calcareous soils. Commun. Soil Sci. Plant Anal 19:1091-1103.

Haridasan M (1992) Observations on soils, foliar nutrient concentrations and floristic composition of cerrado sensu stricto and cerradão communities in central Brazil. In: Furley PA, Ratter, JA (eds), Nature and Dynamics of Forest-Savanna Boundaries. pp.171-184. Chapman \& Hall, London.

Haridasan M (1994) Solos do Distrito Federal. In: NovaesPinto M (ed), Cerrado: Caracterização, ocupação e perspectivas - O caso do Distrito Federal. pp.322-334. Editora Universidade de Brasília/SEMATEC, Brasília.

Haridasan M (2000) Nutrição mineral de plantas nativas do cerrado. Rev. Bras. Fisiol. Veg. 12:54-64.

Haridasan M (2001) Nutrient cycling as a function of landscape and biotic characteristics in the cerrado of central Brazil. In: McClain ME, Victoria RL Richey JE (eds), Biogeochemistry of the Amazon basin and its role in a changing world. pp.68-83. Oxford University Press, New York.

Haridasan M (2005) Competição por nutrientes em espécies arbóreas do cerrado. In: Scariot A, Felfili J M, Sousa-Silva J C (eds), Cerrado: Ecologia, Biodiversidade e Conservação. pp.167-178. Ministério do Meio Ambiente, Brasília.

Haridasan M, Araújo GM (1988) Aluminium-accumulating species in two forest communities in the cerrado region of central Brazil. For. Ecol. Manage. 24:15-26.

Haridasan M, Araújo GM (2005) Perfil nutricional de espécies lenhosas de duas florestas semidecíduas em Uberlândia, MG. Rev. bras. Bot. 28:295-303.

Haridasan M; Hill PG, Russell DG. (1987) Semiquantitative estimates of aluminium and other cations in the leaf tissues of some Al-accumulating species using electron probe microanalysis. Plant and Soil 104:99-102.

Hutchinson DE (1943) The biochemistry of aluminium and certain related elements. Quarterly Reviews of Biology 18:1-29, 123-153, 242-262, 331-363.

Isbell RF (2002) The Australian Soil Classification. Melbourne: CSIRO Publishing. 144p.

Jansen S, Smets E, Haridasan M (2003) Aluminum accumulation in flowering plants. In: Blumel D, Rappaport A (eds), McGraw-Hill Yearbook of Science and Technology. pp.11-13. McGraw-Hill, New York.

Kozovits AR, Bustamante MMC, Garofalo CR, Bucci S, Franco AC, Goldstein G, Meinzer FC (2007) Nutrient resorption and patterns of litter production and decomposition in a Neotropical Savanna. Functional Ecology 2007.

Lathwell, DJ, Grove, TL (1986) Soil-plant relationships in the tropics. Annual Review of Ecology and Systematics 17:1-16.

Lilienfein J, Wilcke W, Zimmermann R, Gerstberger P, Araújo GM, Zech, W (2001) Nutrient storage in soil and biomass of native Brazilian Cerrado. J. Plant Nutr. Soil Sci. 164:487-495.

Lopes AJ, Cox FR (1977) A survey of the fertility status of surface soils under cerrado vegetation of Brazil. Soil Sci. Am. J. 41:752-757.

Lüttge U, Haridasan M, Fernandes GS, W, Mattos ESA, Trimborn P, Franco AC, Caldas LS, Ziegler H (1998) Photosynthesis of mistletoes in relation to their hosts at various sites in tropical Brazil. Trees 12:167-174.

Machado JWB (1985) Acumulação de alumínio em Vochysia thyrsoidea Pohl. Brasília, Universidade de Brasília. Master's dissertation.

Mariano ED, Jorge RA, Keltjens WG, Menossi M (2005) Metabolism and root exudation of organic acid anions under aluminium stress. Braz. J. Plant Physiol. 17:157-172.

Mclaughlin SB, Wimmer R (1999) Calcium physiology and terrestrial ecosystem processes. New Phytol. 142:373417.

Mendonça RC, Felfili JM, Walter BMT, Silva Junior MC, Rezende AV, Filgueiras TS, Nogueira PE (1998) Flora vascular do cerrado. In: Sano SM, Almeida P (eds) Cerrado ambiente e flora. pp.289-539. EMBRAPA, Brasília.

Moraes CDA (1994) Resposta de algumas espécies arbóreas nativas do cerrado à adubação e calagem. Brasília, Universidade de Brasília. Master's dissertation.

Nardoto GB, Bustamante MMC, Pinto AS, Klink CA (2006) Nutrient use efficiency at ecosystem and species level in savanna areas of Central Brazil and impacts of fire J. Trop. Ecol. 22:191-201.

Neri, AV (2007) Gradiente pedológico-vegetacional de Cerrado em Paraopeba, Minas Gerais. Viçosa, Universidade Federal de Viçosa. Ph. D. thesis.

Nogueira PE, Haridasan M (1997) Foliar nutrient concentrations of tree species in four gallery forests in central Brazil. In: Encinas JI, Kleinn C (eds), Proceedings of the International Symposium on Assessment and Monitoring of Forests in Tropical Dry Regions with 
Special Reference to Gallery Forests. pp.309-321. Universidade de Brasília, Brasília.

Oliveira-Filho AT, Shepherd GJ, Martins FR, Stubblebine WH (1989) Environmental factors affecting physiognomic and floristic variation in an area of cerrado in central Brazil. J. Trop. Ecol. 5:413-431.

Prado CHBA, Wenhui A, Rojas MH, Souza GM (2004) Seasonal leaf gas exchange and water potential in a woody cerrado species community. Braz. J. Plant Physiol. 16:7-16.

RADAMBRASIL (1976a) Folha SA 21. Santarém: geologia, geomorfologia, pedologia, vegetação e uso potencial da terra. Departamento Nacional da Produção Mineral, Rio de Janeiro.

RADAMBRASIL (1976b) Folha SD 20. Goiás: geologia, geomorfologia, pedologia, vegetação e uso potencial da terra. Departamento Nacional da Produção Mineral, Rio de Janeiro.

Ratter JA, Askew GD, Montgomery RF, Gifford DR (1977) Observações adicionais sobre o cerradão de solos mesotróficos no Brasil Central. In: Ferri M G (ed), IV Simpósio Sobre o Cerrado. pp.306-316. EDUSP, São Paulo.

Ratter JA, Bridgewater S, Ribeiro JF (2003) Analysis of floristic composition of the Brazilian cerrado vegetation. III. Comparison of the woody vegetation of 376 areas. Edinburgh J. Bot. 60:57-109.

Ratter JA, Furley PA, Montgomery RF, Gifford DR (1978) Observations on forests of some mesotrophic soils in Central Brazil. Rev. bras. Bot. 1:47-58.

Reis MJ (1999) Eficiência micorrízica em plantas nativas do cerrado. Brasília, Universidade de Brasília. Ph. D. thesis.

Rezende M, Curi N, Ker JC, Rezende SB (2005) Mineralogia de solos brasileiros: interpretação e aplicações. Editora UFLA, Lavras.

Ruggiero PGC, Batalha MA, Pivello VR. Meirelles ST (2002) Soil-vegetation relationships in cerrado
(Brazilian savanna) and semideciduous forest, Southeastern Brazil. Plant Ecol. 160:1-16.

Ruggiero PGC, Pivello VR, Sparovek G, Teramoto E, Pires Neto AG (2006) Relação entre solo, vegetação e topografia em área de cerrado (Parque Estadual de Vassununga, SP): como se expressa em mapeamentos? Acta Bot. Bras. 20:383-394.

Silva MEF (2001) Efeitos a longo prazo da calagem e adubação sobre a disponibilidade de nutrientes no solo, a concentração de nutrientes na serapilheira e a nutrição mineral de três espécies lenhosas nativas de um cerrado sensu stricto. Brasília, Universidade de Brasília. Master's dissertation.

Silva IR, Smyth TJ, Barros NF, Novais RF. (2002) Physiological aspects of. aluminum toxicity and tolerance in plants. Tópicos em Ciência Solo 2:277-335.

Souza JP, Araújo GM, Haridasan M (2007) Influence of soil fertility on the distribution of tree species in a deciduous forest in the Triângulo Mineiro region of Brazil. Plant Ecology 19:253-263.

Sternberg LSL, Bucci SJ, Franco AC, Goldstein G, Hoffmann WA, Meinzer FC, Moreira MZ, Scholz F (2005) Long range lateral root activity by neo-tropical savanna trees. Plant Soil 270:169-78.

Townsend AR, Cleveland CC, Asner GP, Bustamante MMC (2007) Controls over foliar N:P ratios in tropical rain forests. Ecology 107-118.

Villela DMV, Haridasan M (1994) Response of the ground layer community of a cerrado vegetation in central Brazil to liming and irrigations Plant Soil 163:25-31.

Vitorello VA, Capaldi FR, Stefanuto VA (2005) Recent advances in aluminum toxicity and resistance in higher plants. Braz. J. Plant Physiol. 17:129-143.

Vitousek PM (1984) Litterfall, nutrient cycling, and nutrient limitation in tropical forests. Ecology 65:285-98.

Webb LJ (1954) Aluminium accumulation in the Australian-new Guinea flora. Aust. J. Bot. 2:176-196. 